\title{
Detecting the Relationship between Adaptation and Learning Performance of Second Generation Immigrant Students in Elementary Schools
}

\author{
Dian-Fu Chang \\ Graduate Institute of Educational Policy and Leadership, \\ Tamkang University \\ New Taipei City, Taiwan \\ 140626@mail.tku.edu.tw \\ Jung-Ta Liu \\ Graduate Institute of Educational Policy and Leadership, \\ Tamkang University, Taiwan
}

\begin{abstract}
This study aims to determine the relationship between student adaptation and learning performance among second generation immigrant children in elementary schools. We collected 364 students' data to fit this scope from New Taipei City in 2013. Statistical analyses include descriptive statistics,one-way ANOVA, Pearson product-moment correlation, and multiple regression analysis. The findings reveal that the second generation immigrant students' adaptation is pretty well compared to that of their counterparts. The learning performance is also better than that of the expected level. The result indicates there is different individual adaptation among second generation immigrant children due to their mother's education attainment. The different interpersonal adaptation has also shown on their father's education attainment. Mother's occupation can explain the differences of family adaptation, learning adaptation, and student's adaptation. The second generation immigrant student's adaptation has shown low positive correlation with their learning performance. The findings may use to enhance second generation immigrant student's adaptation and prompt to their learning performance.
\end{abstract}

Keywords:Second generation immigrant students, immigrant students, student's adaptation, learning performance.

\section{INTRODUCTION}

Students with an immigrant background include secondand first-generation students. Like PISA's classification, three types of immigrant status include: i) native students: students born in the country of assessment with at least one parent born in the country or foreign-born students with at least one parent born in the country of assessment; ii) second-generation students: students born in the country of assessment with both parents foreign-born; iii) first-generation students: foreignborn students whose parents are also foreign-born. Furthermore, the term second-generation can refer to a member of either: the second generation of a family to inhabit, but the first to be natively born in, a country, or the second generation to be born in a country. In this study, we accepted the definition that second generation refers to people born in the country, with at least one first-generation (immigrant)

\author{
Wen-Ching Chou \\ Department of Educational Policy and Administration, \\ National Chi Nan University, Taiwan
}

parent. For example, people born in Puerto Rico or other U.S. territories with at least one parent born in a different country are considered second generation.

During the last two decades, the foreign marriage has become popular in Taiwan. Especially, the new partners come from China and south-east Asia. Since then, the number of immigrant-born generations has been perceived increasing rapidly. During that time, MOE supported three family research centers located in northern, central, and southern areas of Taiwan. These centers have implemented the policy to training volunteers to engage in related educational activities for those second generation immigrant families. After the Family Education Act implementing, each county and city have created their family education centers for eliminate the gap of culture and education. In this study, we focused on the second generation children with one parent born in the country and determine their adaption and learning performance. Given this purpose, this study addressed the following questions:

(a) To what extend do the student's adaptation perceive by second generation immigrant students?

(b) To what extend do the learning performance demonstrate by second generation immigrant students?

(c) What kind of relationship is exerted between student's adaption and learning performance?

\section{LITERATURE REVIEW}

Adaptation theory, also known as survival theory or survival of the fittest, is an organism's ability to adapt to changes in its environment and adjust accordingly over time. In general, adaptations occur over generations of a species with those traits that help an individual animal eat and mate most profusely being passed down from generation to generation until the whole species changes to be better suited to their environment [1]. In education, recent research confirms that immigration results in enormous stress for children. The stress may come from leaving a familiar social context and extended family network, from entering a new 
place, culture, and language, or from harsh conditions endured before or during the transitional journey. Many immigrant children struggle to establish and re-establish themselvesredefining their roles within the family as well as their relationship to a new society - without the support of the strong kinship or friendship systems they had at home, and often without the fulfillment of their basic needs [2].

Previous studies have sought explanations for the marked differences in school performance of immigrant groups who are all poor, as well as for both within-group differences and second- generation decline [3-5]. In United States, many immigrants have been forced to acculturate into very poor neighborhoods and thus become socialized among marginalized populations. This has worked to their disadvantage in so far as it has led to an incorporation of the social behaviors of an American underclass. Delaying or postponing acculturation and promoting ethnic self-identity and cohesiveness may be the best solutions for these poor immigrant families [6]. Vietnamese-American adolescents demonstrated that limited contact with Americanized peers and native-born peers had a positive impact on the youths' adjustment. As many of the Vietnamese American adolescents moved away from their cultural traits and closer to their native born peers' culture, they began assimilating into an underprivileged segment of American society [6].

Within the body of literature on immigrant children and their adaptation to a receiving or host country, two major disciplinary schools of thought overlap: the sociology of migration and anthropology's cultural-ecological theory. Overall, they take a macro view of immigrant groups, often focusing on adults and large processes of integration [6]. Broekkamp, Bernadette\& Hout-Wolters presented a theoretical model that integrates various factors that seem relevant to strategy adaptation in test preparation, including the teacher's intended task demands, students' perceptions of these demands, students' personal goals for studying, and their ability to adapt and implement strategies. The model stimulate our further research on adaptation, which may eventually provide evidence-based guidelines that could help teachers support the development of second generation immigrant students' adaptability [7]. Research on immigration has been useful for educators to better understand the children and families with whom they work. Furthermore, Qin-Hilliard's study drew on longitudinal data to examine the role of gender in immigrant students' educational adaptation. Analyses show that over time girls receive higher grades and express higher future expectations than do boys. Compared with boys, immigrant girls are more likely to be protected from risk factors, such as harsh school environments, by a supported network of teachers, friends, and parents, and to benefit from the shield of ethnicity more than their male counterparts in their pursuit of education [8]. Current knowledge related to immigrant student might be used to interpret the similar phenomena of second generation immigrant students.

\section{METHOD}

In order to collect data from the second generation immigrant students, we designed a student adaption questionnaire which contents 23 items in four dimensions.
There are individual adaptation (6 items), learning adaptation (5 items), family adaptation (5 items), and interpersonal adaptation (7 items). Learning performance is defined as student's previous semester performance which is consisted of writing, mid-term, and final scores, and related performance evaluation. Learning performance has been transformed by percentage of each student. We also considered students' Chinese and Math performance. Statistical analyses include descriptive statistics,one-way ANOVA, Pearson productmoment correlation, and multiple regression analysis.

According to MOE annual report, there are 146,877 second generation immigrant students in elementary education level in 2013. Our target groups are located in New Taipei City, there are 25,730 second generation immigrant students [9]. The details of target research groups and their original countries are listed as TABLE 1.

TABLE 1. THE SECOND GENERATIN IMMIGRANT STUDNETS IN ELEMENTAY EDUCATION LEVEL IN 2013

\begin{tabular}{|l|l|l|l|l|l|l|l|}
\hline $\begin{array}{c}\text { Original } \\
\text { countries }\end{array}$ & Total & First & $\begin{array}{c}\text { Secon } \\
\mathbf{d}\end{array}$ & $\begin{array}{c}\text { Thir } \\
\mathbf{d}\end{array}$ & $\begin{array}{c}\text { Fourt } \\
\mathbf{h}\end{array}$ & $\begin{array}{c}\text { Fift } \\
\mathbf{h}\end{array}$ & $\begin{array}{c}\text { Sixt } \\
\mathbf{h}\end{array}$ \\
\hline China & 10,62 & 1,44 & 1,611 & 1,72 & 1,741 & 2,0 & 2,0 \\
\hline Viet Nam & 10,47 & 977 & 1,236 & 1,73 & 2,070 & 2,2 & 2,1 \\
\hline Indonesia & 1,827 & 198 & 222 & 253 & 332 & 385 & 437 \\
\hline Thailand & 427 & 70 & 65 & 64 & 72 & 75 & 81 \\
\hline Philippine & 494 & 54 & 78 & 78 & 92 & 88 & 104 \\
\hline Cambodia & 307 & 16 & 41 & 46 & 52 & 78 & 74 \\
\hline Japan & 176 & 34 & 31 & 31 & 28 & 32 & 20 \\
\hline Malaysia & 220 & 34 & 32 & 39 & 39 & 29 & 47 \\
\hline $\begin{array}{l}\text { United } \\
\text { States }\end{array}$ & 120 & 19 & 18 & 28 & 21 & 18 & 16 \\
\hline Korea & 98 & 20 & 16 & 16 & 16 & 13 & 17 \\
\hline Myanmar & 661 & 86 & 103 & 102 & 107 & 126 & 137 \\
\hline Singapore & 20 & 2 & 4 & 1 & 3 & 3 & 7 \\
\hline Candia & 41 & 12 & 7 & 9 & 6 & 3 & 4 \\
\hline Others & 244 & 49 & 46 & 34 & 35 & 33 & 47 \\
\hline \begin{tabular}{l} 
New Taipei \\
\hline
\end{tabular} & 25,73 & 3,01 & 3,510 & 4,15 & 4,614 & 5,1 & 5,2 \\
\hline $\begin{array}{l}\text { Nation- } \\
\text { wide }\end{array}$ & 146,8 & 17,1 & 20,04 & 23,7 & 26,77 & 28, & 30, \\
\hline
\end{tabular}

In this study, we employed stratified sampling technique to select the samples in 12 elementary schools. We selected the students in fifth and sixth grade. There are 449 questionnaires sent, finally, we got 364 valid questionnaires. It represents $72.95 \%$ of response rate. The students' background and their distribution have shown in TABLE 2.

TABLE 2. THE SAMPLES AND THEIR SELCTED BACKGROUND INFORMATION

\begin{tabular}{|c|c|c|c|c|}
\hline $\begin{array}{c}\text { Demographic } \\
\text { variables }\end{array}$ & Classify & Students & \% & Cum \% \\
\hline \multirow{2}{*}{ Gender } & Boy & 198 & $54.4 \%$ & $54.4 \%$ \\
\cline { 2 - 5 } & Girl & 166 & $45.6 \%$ & $100 \%$ \\
\hline \multirow{2}{*}{ Grade } & Fifth & 189 & $51.9 \%$ & $51.9 \%$ \\
\cline { 2 - 5 } & Sixth & 175 & $48.1 \%$ & $100 \%$ \\
\hline \multirow{2}{*}{$\begin{array}{c}\text { Mother's } \\
\text { nationality }\end{array}$} & Viet Nam & 176 & $48.4 \%$ & $48.4 \%$ \\
\cline { 2 - 5 } & China & 93 & $25.5 \%$ & $73.9 \%$ \\
\cline { 2 - 5 } & Indonesia & 42 & $11.5 \%$ & $85.4 \%$ \\
\cline { 2 - 5 } & Kampuchea & 6 & $1.6 \%$ & $87.0 \%$ \\
\hline
\end{tabular}




\begin{tabular}{|c|c|c|c|c|}
\hline & Philippine & 11 & $3.0 \%$ & $90.0 \%$ \\
\hline & Thailand & 9 & $2.5 \%$ & $92.5 \%$ \\
\hline & Malaysia & 4 & $1.1 \%$ & $93.6 \%$ \\
\hline & Others & 23 & $6.3 \%$ & $100 \%$ \\
\hline \multirow[t]{4}{*}{$\begin{array}{c}\text { Family } \\
\text { structure }\end{array}$} & $\begin{array}{c}\text { Single parent } \\
\text { family }\end{array}$ & 74 & $20.3 \%$ & $20.3 \%$ \\
\hline & Nuclear family & 184 & $50.5 \%$ & $70.8 \%$ \\
\hline & Large family & 89 & $24.5 \%$ & $95.3 \%$ \\
\hline & $\begin{array}{c}\text { Live with } \\
\text { grand parent or } \\
\text { others }\end{array}$ & 17 & $4.7 \%$ & $100 \%$ \\
\hline \multirow{4}{*}{$\begin{array}{c}\text { Mother's } \\
\text { education } \\
\text { attainment }\end{array}$} & $\begin{array}{c}\text { Junior high } \\
\text { school }\end{array}$ & 198 & $54.4 \%$ & $54.4 \%$ \\
\hline & $\begin{array}{l}\text { Senior high } \\
\text { school }\end{array}$ & 136 & $37.4 \%$ & $91.8 \%$ \\
\hline & College & 27 & $7.4 \%$ & $99.2 \%$ \\
\hline & Graduate & 3 & $0.8 \%$ & $100 \%$ \\
\hline
\end{tabular}

\section{RESULTS}

\section{A. Interpretation of Adaptation}

The student's demography, in terms of mother's occupation makes difference in student adaptation, specifically, there is a significant difference in family adaptation and learning adaptation with this variation. Mother's education attainment also shows difference in individual adaptation. Father's education attainment has shown significant difference in interpersonal adaptation. The result revels there is no significant gender difference in student adaptation among the second generation immigrant students. Considered the four different dimensions of student adaptation, we also found there is no gender difference. The other variables also show no significant difference, see TABLE 3.

TABLE 3. THEDIFFERENCESOF ADAPTATION BY STUDENT'S BACKGROUND VARIABLES

\begin{tabular}{|c|c|c|c|c|c|}
\hline $\begin{array}{c}\text { Dimensions } \\
\text { Demography } \\
\text { variables }\end{array}$ & $\begin{array}{c}\text { Individua } \\
\text { I adapt. }\end{array}$ & $\begin{array}{c}\text { Famil } \\
\mathbf{y} \\
\text { adapt. }\end{array}$ & $\begin{array}{c}\text { Learning } \\
\text { adapt. }\end{array}$ & $\begin{array}{c}\text { Inter- } \\
\text { person } \\
\text { al } \\
\text { adapt. }\end{array}$ & $\begin{array}{c}\text { Studen } \\
\text { t } \\
\text { adapt. }\end{array}$ \\
\hline Gender & ns. & ns. & ns. & ns. & ns. \\
\hline Grade & ns. & ns. & ns. & ns. & ns. \\
\hline $\begin{array}{c}\text { Mother's } \\
\text { nationality }\end{array}$ & ns. & ns. & ns. & ns. & ns. \\
\hline $\begin{array}{c}\text { Family } \\
\text { structure }\end{array}$ & ns. & ns. & ns. & ns. & ns. \\
\hline $\begin{array}{c}\text { Father's } \\
\text { education } \\
\text { attainment }\end{array}$ & ns. & ns. & ns. & Sig. & ns. \\
\hline $\begin{array}{c}\text { Mother's } \\
\text { education } \\
\text { attainment }\end{array}$ & $\begin{array}{c}\text { Senior } \\
\text { high }> \\
\text { junior } \\
\text { high }\end{array}$ & ns. & ns. & ns. & ns. \\
\hline $\begin{array}{c}\text { Father's } \\
\text { occupation }\end{array}$ & ns. & ns. & ns. & ns. & ns. \\
\hline $\begin{array}{c}\text { Mother's } \\
\text { occupation }\end{array}$ & ns. & Sig. & Sig. & ns. & Sig. \\
\hline
\end{tabular}

Note. ns.= no significant difference;

sig. represents significant difference

\section{B. Interpretation of Learning Performance}

The average of learning performance among these immigrant students is 87.26 , $\mathrm{SD}=7.11$ (in the evaluation scale from 0 to 100), which is above the average of their classmates. The average of Chinese performance is 88.20, $\mathrm{SD}=7.52$, while the average of Math is 82.57, SD $=11.75$. The Math performance has shown a bigger deviation, it reflects the individual difference in this group. Compare their learning performance of second generation immigrant groups, we found these groups do better than that of regular classes.

\section{Interpretation of Relationship}

The relationship between student adaptation and learning performance has shown positive correlation $(\mathrm{r}=.32$, $\mathrm{p}<.01)$. The correlation between student adaptation and Chinese performance is $\mathrm{r}=.330(\mathrm{p}<.01)$, while relationship between student adaptation and Math performance is $\mathrm{r}=.186(\mathrm{p}<.01)$. In our regression model (model 1) for learning performance explained by student adaptation has shown that learning adaptation can explain $16.7 \%$ of learning performance (R $=.409, \mathrm{p}<.01)$. Model 2 shows that learning adaptation can explain $17.5 \%$ of Chinese performance $(\mathrm{R}=.419, \mathrm{p}<.01)$. Model 3 shows that both leaning adaption and interpersonal adaption can explain $16.4 \%$ of Math performance $(\mathrm{R}=.405$, $\mathrm{p}<.01)$. These models are fit the tolerance criteria VIF $<10$, see TABLE 4.

TABLE 4. REGRESSION MODELS FOR LEARNING PERFORMANCE EXPLAINED BY STUDENT'S ADAPTATION

\begin{tabular}{|c|c|c|c|c|c|c|c|}
\hline Model & $\begin{array}{l}\text { Independe } \\
\text { nt variable }\end{array}$ & $R$ & $R^{2}$ & Beta & t-test & $p$ & VIF \\
\hline \multirow[t]{2}{*}{1} & (Constant) & \multirow[b]{2}{*}{.409} & \multirow[b]{2}{*}{.167} & & 41.850 & .000 & \\
\hline & $\begin{array}{c}\text { Learning } \\
\text { Adaptation }\end{array}$ & & & .409 & 8.534 & .000 & 1.000 \\
\hline \multirow[t]{2}{*}{2} & (Constant) & \multirow[b]{2}{*}{.419} & \multirow[b]{2}{*}{.175} & & 39.625 & .000 & \\
\hline & $\begin{array}{c}\text { Learning } \\
\text { Adaptation }\end{array}$ & & & .419 & 8.776 & .000 & 1.000 \\
\hline \multirow[t]{3}{*}{3} & (Constant) & \multirow{3}{*}{.405} & \multirow{3}{*}{.164} & & 22.015 & .000 & \\
\hline & \begin{tabular}{|c|} 
Learning \\
Adaptation \\
\end{tabular} & & & .581 & 8.202 & .000 & 2.169 \\
\hline & $\begin{array}{c}\text { Inter-personal } \\
\text { Adaptation }\end{array}$ & & & -.335 & -4.724 & .000 & 2.169 \\
\hline
\end{tabular}

Note. Model 1: Dependent variable = Learning

Performance;

Model 2: Dependent variable $=$ Chinese;

Model 3: Dependent variable $=$ Math; $\mathrm{N}=364$

\section{DISCUSSION AND CONCLUSION}

This study demonstrates that second generation immigrant students' adaptation is better than our expected level. The adaptations in terms of individual, family, learning, and interpersonal adaptation have shown well in this survey. The average of learning performance among these immigrant students is higher than that of their regular classmates. The special phenomena might diverse from the other countries, but it could be explained by the effect of policy intervention in recently. Since the government has initiated couple projects to eliminate the gap of culture and education for second generation immigrant students and their parents.

Based on the findings, we are arguing for the need to create the space where second generation immigrant students' experiences and perceptions are allowed to be expressed, understood, and built upon in schools. In the education setting, the commonly stated goal is for the classroom to function as a 
learning community. If we can build true learning communities, the immigrant students' lives should no longer remain hidden from the view of their peers and teachers.

\section{REFERENCES}

[1] S. King, "What is adaptation theory?" eHow Contributor. Retrieved fromhttp://www.ehow.com/about_5105998_adaptation-theory.html.

[2] K. McCarthy, "Adaptation of immigrant children to the United States: A review of the literature", Center for Research on Child Wellbeing Working Paper \#98-03. Retrieve from http://crcw.princeton.edu/workingpapers/WP98-03-McCarthy.pdf, 2014

[3] D. Howard-Rose, and C. Rose, "Students' adaptation to task environments in resource room and regular class settings”, Journal of Special Education, vol. 28, no. 1, spring 1994, pp. 3-26.

[4] C. L. Bankston III, and M. Zhou, "Being well vs. doing well: Selfesteem and school performance among immigrant and nonimmigrant racial and ethnic groups”, International Migration Review, vol. 36, no. 2, June 2002, pp. 389-415, doi: 10.1111/j.1747-7379.2002.tb00086.x

[5] R. G. Rumbaut, "Ties that bind: Immigration and immigrant families", in A. Booth, A. C. Crouter, and N. S. Landale, Eds., Immigration and the family: Research and policy on U.S. immigrants, pp. 3-46, Lawrence Erlbaum Associates, 1997. Retrieved from http://ssrn.com/abstract=1888727

[6] P. Sanchez, G. S. Kasun, "Connecting transnationalism to the classroom and to theories of immigrant student adaptation. Berkeley Review of Education, 3(1), online, 2012

[7] H. Broekkamp, H. A. M. Bernadette, and V. Hout-Wolters, "Students' adaptation of study strategies when preparing for classroom tests". Education Psychology Review, no. 19, 2007, pp. 401-428, doi: 10.1007/s10648-006-9025-0

[8] D. B. Qin-Hilliard, "Gendered expectations and gendered experiences: Immigrant students' adaptation in schools”, New Directions for Youth Development,no. 100, pp. 91-109, 2003,doi: 0.1002/yd.65

[9] MOE, "The number of second generation immigrant students by their parent's nationality”, Retrieved from http://www.edu.tw/pages/detail.aspx?Node=4076\&Page=20047\&Index $=5 \& W I D=31 d 75 a 44-$ efff-4c44-a075-15a9eb7aecdf 